\title{
Okul Öncesi Öğretmenlerinin Sesbilgisel Farkındalık Kavramına Yönelik Bilgi Düzeyleri ve Sınıf İçi Etkinlikler
}

\author{
Deniz AKDAL \\ Kurşehir Ahi Evran Üniversitesi \\ deniz.akdal@ahievran.edu.tr \\ ORCID: 0000-0001-9272-3422
}

\begin{tabular}{lrr} 
Araştırma Makalesi & DOI: $10.31592 /$ aeusbed.653877 \\
\hline Geliş Tarihi: 02.12 .2019 & Revize Tarihi: 01.07 .2020 & Kabul Tarihi: 02.07.2020
\end{tabular}

\section{Atıf Bilgisi}

Akdal, D. (2020). Okul öncesi öğretmenlerinin sesbilgisel farkındalık kavramına yönelik bilgi düzeyleri ve sınıf içi etkinlikler. Ahi Evran Üniversitesi Sosyal Bilimler Enstitüsü Dergisi, 6(2), 496-515.

\section{$\ddot{O z}$}

$\mathrm{Bu}$ çalışmada okul öncesi öğretmenlerin sesbilgisel farkındalık kavramına yönelik bilgi düzeylerinin belirlenmesi ile sesbilgisel farkındalık becerilerin çocuklara kazandırılmasında kullandıkları sınıf içi etkinlikler incelenmiştir. Verilerin elde edilmesinde araştırmacı tarafindan oluşturulan ve 7 açık uçlu sorudan oluşan“öğretmenlerin sesbilgisel farkındalık becerileri ile ilgili bilgilerini ve sınıf içi uygulamalarını belirlemeye yönelik görüşme formu" kullanılmış ve veriler görüşmeye dayalı olarak toplanmıştır.18 okul öncesi eğitim öğretmeninden veriler toplanmış ve nitel araştırma yöntemlerinden içerik analizi kullanılarak bulgular elde edilmiştir. Elde edilen bulgular nitel araştırma yöntemlerinden görüşmeye dayalı tümevarım analiz modelinde tasarlanmış ve analiz edilmiştir. Elde edilen bulgulara bakıldığında araştırmaya katılan 18 okul öncesi öğretmenin tamamının sesbilgisel farkındalık kavramının adını bilmedikleri, ayrıca 18 okul öncesi öğretmenin bu kavrama ait becerileri ve bu becerilerin gelişimlerini bilmedikleri tespit edilmiştir. 4 okul öncesi öğretmenin ise sesbilgisel farkındalık becerilerine yönelik etkinlik hazırladıkları fakat hiçbir okul öncesi öğretmenin sesbilgisel farkındalık becerileri edinim sürecine ilişkin çocuklara değerlendirilme yapmadıkları tespit edilmiştir. Tartışmada okul öncesi öğretmenlerden elde edilen bulgular ayrıntıları ile ele alınmıştır.

Anahtar Kelimeler: Sesbilgisel farkındalık, sınıf içi etkinlikler, okul öncesi.

\section{The Knowledge Levels of Pre-School Teachers about the Concept of Phonological Awareness and Classroom Activities}

\begin{abstract}
This study aimed to determine the knowledge levels of preschool teachers regarding the concept of phonological awareness and to examine the in-class activities they use for the acquisition of phonological awareness skills by children. To obtain the data, "the interview form for determining the knowledge of teachers regarding phonological awareness skills and their in-class practices," which was created by the researcher and consisted of 7 open-ended questions, was used, and the data were collected on the basis of the interviews. The data were collected from 18 preschool teachers, and the findings were obtained through the content analysis, which is one of the qualitative research methods. The findings obtained were designed and analyzed in the interview-based inductive analysis model, one of the qualitative research methods. When the findings were reviewed, it was found out that none of the 18 preschool teachers, who participated in the study, knew the name of the phonological awareness concept; moreover, these 18 preschool teachers did not know about the skills related to this concept and the development of these skills. It was determined that four preschool teachers prepared activities for phonological awareness skills; however, no preschool teachers made evaluations on children with respect to the acquisition process of phonological awareness skills. In the discussion section, the findings obtained from preschool teachers are addressed in detail.
\end{abstract}

Keywords: Phonological awareness, classroom activities, preschool.

\section{Giriş}

Çocukların erken dönemde formal okuma-yazma öğretimine başlamadan önceki dönemde, okuma yazma becerilerine ilişkin edinmeleri gereken önkoşul bilgi, beceri ve tutumlarının tamamı erken okuryazarlık olarak ifade edilmektedir (Sulzby and Teale, 1991; Whitehurst and Lonigan, 1998). Erken okuryazarlık kavramına yönelik araştırmaların başlamasıyla birlikte erken okuryazarlık terimi ve erken okuryazarlık becerileri alanyazın da daha çok yer bulmaya başlamıştır (Baydık, 2003). Bu becerilerin temellerinin atıldığı erken okuryazarlık bu süreç öncesinde önem kazanmaktadır. Erken okuryazarlık becerilerinin okuma sürecindeki yeri ve işlevine bakıldığında, bu becerilerden bazılarının 
(yazı farkındalığı, sesbilgisel farkındalık ve harf bilgisi) okumanın doğrudan sözcük çözümleme basamağına, bazılarının (sözcük bilgisi, sesbilgisel farkındalık, dinlediğini anlama) ise hem sözcük çözümleme hem de okuduğunu anlamaya önemli katkılar yaptıkları dikkati çekmektedir (Kargın, Güldenoğlu ve Ergül, 2017). Birey kelime çözümleme sürecinde hız kazanması ve bu çözümlediği kelimeler ile dil bağlamında anlam kurması bu iki sürecin etkileşimli hale getirilmesi okuma başarısı için gereklidir. Erken okuryazarlık becerileri içerisinde bulunan geniş sözcük bilgisi becerisine sahip çocuklar okuma sırasında çözümledikleri kelimeleri daha doğru ve akıcı okuyacaktır böylelikle okuduğunu anlama becerilerini olumlu etkileyecektir (Bodle, 2019). Alanyazında sözcük bilgisi ile yapılan boylamsal çalışmalar sözcük bilgisi becerisinin okuduğunu anlama becerileri ile doğrusal bir ilişki olduğunu göstermektedir (Yedi, Hull, Madsen, Ferron, Sanders, Soto Kelley ve Goldstein, 2020). Bir diğer erken okuryazarlık becerileri arasında yer alan yazı farkındalığ 1 , yazılı dilinin ve yazım kurallarının anlaşılmasını içermektedir. Bu içerikte "çevresel yazıların anlaşılması, kitap kavramları, yazının yönü, sözcükler arasındaki boşluklar, sözcük, cümle gibi yazıyı oluşturan birimleri ifade eden yazı kavramları ve alfabe bilgisi" yer almaktadır (Thomas, Gerde, Piasta, Logan, Bailet ve Zetter-Greeley, 2020). Çocukların yazının bir işlevi olduğunu anlaması, metin yönünü bilmesi ve karmaşı olan ünlem, soru işareti vb. yazılı sembollerin işlevlerini bilmesi onları okuma yazma öğretimine karşı daha istekli olmalarını sağlamaktadır. Önemli bir beceri olan dinlediğini anlama becerilerinde isebaşarılı olan çocuklar dilin sözdizimsel ve morfolojik yapılarında da başarı göstermektedir. Bu durum çocukların okuduğunu anlamalarını kolaylaştırmaktadır (Tomblin, Oleson, Ambrose, Walker ve Moeller, 2020). Çocukların işitsel ve görsel algıları ile etkileşimli olan diğer bir becersi ise harf bilgisidir. Harf bilgisi çocukların ilerleyen dönemde sözcük çözümleme becerisilerinin ön koşul becerileri oluşturmaktadır (Gerde, 2019) ve harf bilgisinde önemli olan çokcuğun harfin ismini doğrudan bilmesi değil çevresinde yer alan nesneler ile harfler arasında anlamlı bağlar kurmasidir.

Erken okuryazarlık becerileri içerisinde önemli bir beceri olarak görülen ve bu beceriler arasında ön plana çıkan sesbilgisel farkındalık becerisi (Schatschneider, Francis, Foorman, Fletcher ve Mehta, 1999) en genel tanımıyla dilin ses yapısı üzerine düşünme ve sesi değiştirme yeteneği (Scarborough, 2001) olarak tanımlanmaktadır. Söylenişleri benzer olan kelimeleri eşleştirme ve ayırt etme, sözcükleri hecelerine ayırma, ses yinelemesine dayalı becerileri bünyesinde barındıran, bir sözcükte yer alan sesbirim sayısını hesaplayabilme, farklı hece yapısındaki sözcükleri sesbirimlerine ayırabilme, sözcüklerde yer alan sesbirimleri birbirleri ile değiştirebilme gibi çeşitli becerileri içeren sesbilgisel farkındalık becerisi, alfabetik ilkeye dayalı harf-ses ilişkilerinin sözcük yapısındaki sesbilgisel organizasyonunu anlama becerisi olarak tanımlanmaktadır (Wright ve Jacobs, 2003). Sesbilgisel farkındalığı oluşturan bu becerilerin edinim aşamaları ve sırası alanyazında önemli bir yer tutmaktadır. Sesbilgisel farkındalık becerileri söylenişleri benzer olan kelimeleri fark edebilme, heceleri fark edebilme, kelimelerin ilk seslerini ve son seslerini fark edebilme, sesleri birleştirerek sözcükler oluşturabilme, sözcükleri sesbirimlerine ayırabilme, kelimelerdeki sesleri atma gibi bir büyük birimlerden küçük birimlere doğru ilerleme ve edinim sırası izlemektedir (Schule, Skibbe ve Rao, 2007). Sesbilgisel farkındalık becerileri birbirlerinin ön koşul becerileri değildir fakat birbirleri ile paralele olarak gelişme göstermektedir. Bir çocuk bir beceride farklı bir düzeyde iken farklı bir beceride farklı bir düzeyde olabilmektedir. Kelimeleri tanımayı öğrenirken, aynı zamanda bazı kelimelerin kafiyeli olduğunu da fark eder (Gutiérrez-Palma, Naranjo, Justicia-Galiano ve Fernández, 2019). Ülkemizde bu alan da yapılan çalışmaların sayısı az olsada son yıllarda sesbilgisel farkındalık becerilerinin farklı alanlarına yönelik çalışmalar yapılmaktadır. Güldenoğlu, Kargın ve Ergül (2016) yılında yapılan çalışmada sesbilgisel farkındalık becerilerinin okuduğunu anlama üzerinde etkisini boylamsal olarak incelemişler. Erken dönemde sesbilgisel farkındalık becerilerinde iyi performans gösteren çocukların ilerleyen dönemde çözümlemeyi hızlı yaptıklarıi, bu yüzden okuma sırasında zamanı anlamaya ayıra bildiklerini tespit etmişlerdir. Bir başka çalışmada Altun, Tantekin Erden ve Snow (2016) yılında yaptıkları çalışmada ev içi kaynakların sesbilgisel farkındalık becerileri üzerinde etkili olduğunu bulmuşlardır. Alanda yapılan başka bir çalışmada Turan ve Akoğlu (2014) normal gelişim gösteren ve dil bozukluğu olan Türk çocukların sesbilgisel farkındalık becerileri ve ailede sağlanan erken okuryazarlık deneyimlerine göre sesbilgisel farkındalık becerilerinde farklılıklar olduğunu tespit etmişlerdir. Parpucu ve Dinç (2017) tarafinda geliştirilen seslerin renkli dünyası müdahele programı ile okul öncesi dönem çocuklarının sesbilgisel farkındalık becerilerinin 
geliştirilmesi çalışması yapılmışlardır. Genel olrak bakıldıldığında sesbilgisel farkındalık becerilerin gelişimine odaklanan çalışmalara, ev ve okul ortamlarının içeriklerinin sesbilgisel farkındalık beceriler üzerindeki etkilerine ve farklı yetersizliği olan çocuklar üzerinde çalışmalar yapıldığı görülmektedir.

Başarılı bir okuma için erken dönem kazanılması gereken becerilerin önem kazanması ile okul öncesi dönemde okumayı yazma alanında yer alan becerilerde önem kazanmaya başlamıştır (Altun ve Tanetekin Erden, 2016). Okul öncesi dönemde sesbilgisel farkındalık becerilerinin kazandırıldığı ortamlardan biri okul kurumlarıdır (Altun ve Tantekin-Erden, 2016). Alan yazına bakıldığında yurt dışında sesbilgisel farındalık becerilerinin gelişimini destekleyici bütün erken okuryazarlık becerileri bünyesinde barındıran programlar yer almaktadır (Evangelou ve Sylva, 2003; Israel, 2007). Ülkemizde okul öncesi eğitim programında (2013) sesbilgisel farkındalık sadece dil bölümüne ilişkin 9 . kazanımda "Ses bilgisi farkındalığı gösterir. (Göstergeleri: Sözcüklerin başlangıç seslerini söyler. Sözcüklerin sonunda yer alan sesleri söyler. Aynı sesle başlayan sözcükler üretir. Aynı sesle biten sözcükler üretir. Şiir, öykü ve tekerlemedeki uyă̆ı söyler. Söylenen sözcükle uyakl başka sözcük söyler.)" şeklinde bir kazanım yer almaktadır. Bu durum okuma başarısında yordayıcı beceriler arasında yer alan sesbilgisel farkındalık becerilerinin (Kargın, Güldenoğlu ve Ergül, 2016) okul öncesi eğitim programımızda yok denecek durumda olduğunu göstermektedir.

Erken dönemde kazanılan sesbilgisel farkındalık becerilerinin kazandırıldığı ortamlardan biriside okuldur ve okul ortamında geliştirilen çalışmalar, okuma ve yazma görevlerinde başarısız olmayı engelleyerek okul başarısını güçlendirmektedir (Ferraz, Pocinho, Pereira ve Pimenta, 2015). Çünkü ilk okuma becerilerinin edinilmesiyle bağlantılı olduğuna ve okuma güçlüğünün belirleyicisi olabileceğine dair bir araştırma bulguları bulunmaktadır (Brady, Braze ve Fowler, 2011). Ayrıca bu becerileri çocukların kazanması onları ileriki dönemde iyi birer okuyucu olmalarına katkı sağlayacaktır (Ong, 2008). Okul öncesi dönemde çocukların sesbilgisel farkındalık becerilerine yönelik etkinlikler ile karşılaşmaları çocukların okuma için gereken ön koşul becerileri kazanmalarında (Ong, 2008) ve ilerideki okuma başarısın da etkili olmaktadır (Bradley ve Bryant, 1983; Lundberg, Olofsson ve Wall, 1980; Torgeson, Wagner ve Rashotte, 1994). Pek çok araştırma, sesbilgisel farkındalık becerilerinin daha sonraki okuma başarısında önemli olduğunu göstermektedir. (Adams, 1990; Nielsen ve Luetke-Stahlman, 2002). Bu derece önem arz eden sesbilgisel farkındalık becerilerinin çocuklara kazandırılmasında okul öncesi öğretmenleri önemli bir unsuru oluşturmaktadır. Okul öncesi öğretmenlerinin sesbilgisel farkındalık becerilerine yönelik verdikleri eğitimlerin içeriklerinin uygun olması çocukların sesbilgisel farkındalık becerileri açısından yetkin olmasını sağlamaktadır (Pullen ve Justice, 2003). Türkiye'de ise öğretmenler sesbilgisel farkındalık becerilerin kazanımında öğretim etkinliklerini yeterli sıklıkta kullanmamaktadırlar (Emir, 2015). Bir öğretmenin, sesbilgisel farkındalık becerilerinin öğretiminde yeterliliğine ve yetersizliğine ilişkin çeşitli faktörler bulunmaktadır (Yopp ve Yopp, 2000). İlki sesbilgisel farkındalık kavramının yanlış anlaşılmasıdır. Pek çok öğretmen, sesbilgisel farkındalığın ses okuma bilgisi ya da dilin bütünü gibi eski terimler için kullanılan yeni bir terim olduğuna inanmaktadır (Bueno, Darling-Hammond ve Gonzales, 2010; Yopp ve Yopp, 2009). Bir başka neden ise, sesbilgisel farkındalığın dil edinimindeki gelişimsel ilerlemesine ilişkin anlayış eksikliğidir (Whitebook ve Ryan, 2011). Sesbilgisel farkındalığa dair net tanımlar ve açıklamalar olsa da öğretim aşamasında kullanılan tekniklerin ve müdahalelerin okuryazarlık çerçevesinde uygulanması, öğretmenin sesbilgisel farkındalıktan ne anladığının doğrudan bir yansımasıdır (Chu, Martinez-Griego ve Cronin, 2010). Okul öncesi dönem çocukları ile çalışan birçok öğretmenler, okuma programları ve müfredatlar arasındaki geçiş ve değişikliklerin farkında olmaması ayrı bu becerilerin çocuklara kazandırılamamasındaki bir diğer etkendir (Arıcı ve Bartan, 2020; Barnett, Carolan, Squires, Clarke-Brown ve Horowitz, 2015; Cesur ve Demir, 2020).

Okul öncesi öğretmenlerinin sesbilgisel farkındalığın anlamı konusunda bilgi sahibi olup olmadığı ve sesbilgisel farkındalığı öğretecek uzmanlıklarının bulunup bulunmadığına dair kaygılarda alan yazında yer almaktadır (Bos, Mather, Dickson, Podhajski ve Chard, 2001). Öğretmenlerin sesbilgisel farkındalık kavramı hakkındaki bilgi ve becerilerini konu alan araştırmaların olmaması, okuryazarlık edinimi alanında çeşitli okul ve öğrenme ortamlarındaki öğrenci başarısı için gerekli olan beklenti ve tutarlılıklara ilişkin endişeleri daha da arttırmaktadır (Whitebook ve Ryan, 2011). Bunun sebepleri arasında, ileri dönemde sınıf içi öğrenme alanlarının sesbilgisel farkındalık araştırmalarının 
gelişim hızını yakalayamamasından ya da okul öncesi programlarının sesbilgisel farkındalık kavramını bünyelerinde nasıl barındırması gerektiğine yönelik bilgi eksikliğinden kaynaklanmaktadır (Lehr ve Osborn, 1994). Sesbilgisel farkındalık öğretim yaklaşımlarını uygulamak için gereken deneyim, değerler, bilgi ve beceri, öğrencilerin sesbilgisel farkındalık becerilerini öğrenmesini doğrudan etkilemektedir (Baker ve McLeod, 2011; Oliveira, Lousada ve Jesus, 2015; Robinson, 2010). Okul öncesi sınıflarda sesbilgisel farkındalık becerilerin çocukların kazanmalarına yönelik öğretim veren öğretmenlerin sesbilgisel farkındalık konusunda daha derin bir bilgi, beceri ve tutuma sahip olması ve bunları çocuklara aktarması beklenmektedir (Bueno, Fonseca, Braga ve Miranda, 2010). Sesbilgisel farkındalık öğretim aşamasında, sesbilgisel farkındalık kavramına ait bilgi, beceri ve tutumların sınıfa etkili bir şekilde aktarılabilmesi için, öğretmenin bu alanda yeterli bilgi ve becerilerle donanmış olması beklenmektedir. Ayrıca eğitim ve öğretimin gerçek-dünyadaki deneyimlerle ilişkilendirilmesi gerekmektedir (Marvelli, 2010). Okul öncesi öğretmenlerin sesbilgisel farkındalık kavramına yönelik deneyim ve bilgileri ne kadar fazla ise çocukların sesbilgisel farkındalık kavramına yönelik becerileri alanlarında ustalaşması o kadar artmaktadır (Hilbert ve Eis, 2014; Macrae, Tyler ve Lewis, 2014; Robinson, 2010). Sesbilgisel beceriler sadece okumayı değil, sessiz okuma, sözlü dil becerileri, heceleme, dinleme becerisi, sözlü iletişim, okuduğunu anlama ve imla gibi okur-yazarlığın bütün yönlerini etkilemektedir ve etkileri ikinci dil öğrenimi ve müzik yeteneğine de uzanabilmektedir (AlBataineh ve Sims-King, 2013; Chetail ve Mathey, 2010; Metsala, 2011). Okul öncesi y1llarda sesbilgisel farkındalıkla karşılaşmak ve bu konuda eğitilmek, çocuklara okuma için gereken becerileri kazandırıp, anaokuluna daha iyi hazırlayabilir (Ong, 2008).

Sonuç olarak yukarıda sunulan tüm bilgiler birlikte düşünüldüğünde, okuyucuların sahip oldukları sesbilgisel farkındalık bilgi ve becerilerin onların ileriki dönemde okuma performansları üzerinde etkilerinin olduğunu göstermektedir. Alan yazın taramasında bu konuya ilişkin yapılan birçok çalışma olduğu görülmektedir ancak yapılan çalışmaların tamamına yakınının yurt dışında yapıldığı görülmektedir (Ciesielski ve Creaghead, 2020; Yopp ve Yopp, 2009). Konuya ilişkin Türkiye'de yapılmış çalışmalara bakıldığında (Altun Tantekin-Erden, 2016; Girgin, 2012; Emir, Girgin ve Karasu, 2015; Ergül vd., 2014; Güney, 2012) ise az olduğu görülmektedir. Nitekim ulusal alanyazında bu konuda yapılmış çalışmalara bakıldığında, çalışmaların büyük bir çoğunluğunda okuyucuların okumada karşılaş̧ıkları problemlerin yabancı dillerde gerçekleştirilmiş olan çalışmalardan elde edilen bulgularla açıklanmaya çalışıldığı görülmektedir. Hâlbuki tamamen farklı bir dil yapısı olan ve saydam ortografide oluşan Türkçe gibi bir dilde okuma öğrenen çocukların temel okuma becerilerinin kazandırılmasında öğretmenlerin yerinin ve öneminin araştırılması gerekmektedir. $\mathrm{Bu}$ açıdan düşünüldüğg̈nde, hem ulusal alanyazındaki bu önemli boşluğun doldurulması ve öğretmenlerin çocukların sesbilgisel bilgi ve becerileri arasındaki ilişkilerin tanımlanabilmesi için ek araştırmalara ihtiyaç duyulmaktadır. Tüm bu nedenlerden dolayı bu çalışmada, öğretmenlerin çocuklara sesbilgisel farkındalık bilgi ve beceri öğretiminde ne durumda olduklarının belirlenmesi amaçlanmıştır. $\mathrm{Bu}$ doğrultuda sesbilgisel farkındalık becerilerini çocuklara kazandırılması ve bu becerileri çocuklara edindirme aşamasındaki öğretmenlerin gerekli olan bilgi ve becerilere sahip olması gerektiğinin önemli olduğu düşünülmektedir.

\section{Yöntem}

$\mathrm{Bu}$ bölümde araştırmanın modeli, çalışma grubu, veri toplama aracı ve verilerin analizine ilişkin detaylı bilgiye yer verilmiştir.

\section{Araştırmanın Modeli}

$\mathrm{Bu}$ çalı̧̧ma nitel araştırma yöntemleri kapsamında yapılandırılmıştır. Bu çalışmada nitel araştırma yöntemlerinden görüşmeye dayalı tümevarım analiz modelinde tasarlanmıştır. Çalışmada okul öncesi öğretmenlere yönelik dikkatlice hazırlanmış ve belirli sıraya konmuş, görüşmeci yanlılığını veya öznelliğini azaltan yapılandırılmış görüşme tekniği (Yıldırım ve Şimşek, 2008) uygulanmıştır. Bu teknik ile okul öncesi öğretmenlerinin sesbilgisel farkındalık bilgi düzeyleri ve sesbilgisel farkındalık becerilerini geliştirmeye yönelik kullandıkları sınıf içi etkinlikleri hakkında derinlemesine bilgi edinilmesi amaçlanmıştır. Okul öncesi öğretmenlerin yapılandırılmış görüşme 
formuna verdikleri cevaplardan temalar oluşturulmuş ve yanıtlar arası ilişkiler incelenmiştir. Yarı yapılandırılmış görüşme formunun hazırlanmasında alan taraması yapılmış tarama sonrasında okul öncesi öğretmenlere yönelik olası görüşme soruları oluşturulmuştur. Hazırlanan görüşme sorularına ilişkin ilgili alanda çalışan üç uzmandan görüş alınmıştır. Hazırlanan sorulardan 6's1 hazırlandığg gibi kalmışken alan uzmanlarının görüşleri doğrultusunda "Sesbilgisel farkındalık becerilerine yönelik geliştirilen etkinliklere ilişkin görüşleriniz nelerdir?" ve "Sesbilgisel farkındalık becerilerine yönelik etkinliklerin hazırlanmasında nelere dikkat etmektesiniz?" soruları birleştirilerek "Okul öncesi dönemde sesbilgisel farkındalık becerilerinin geliştirilmeleri ile ilgili olarak ne tarz etkinlikler yapmakta ve bu etkinliklerin oluşturulma sürecinde nelere dikkat etmektesizin?" şeklinde değiştirilmiştir. Görüşmeler sırasında öğretmenlere sorulan sorular "Sesbilgisel kavramını nasıl tanımlarsınız? Sesbilgisel farkındalık becerilerinin gelişimi ve düzeylerini nasıl tanımlarsınız? Sesbilgisel farkındalık kavramının önemi hakkında düşünceleriniz nelerdir? Okul öncesi dönemde sesbilgisel farkındalık becerilerinin geliştirilmeleri ile ilgili olarak ne tarz etkinlikler yapmakta ve bu etkinliklerin oluşturulma sürecinde nelere dikkat etmektesizin Çocukların sesbilgisel farkındalık becerilerin değerlendirilmesinde neler yapmaktasınız? Sesbilgisel farkındalık becerilerinin çocuklara kazandırılması aşamasında karşılaşılan sorunlar nelerdir?” bu sıra ile verilmiştir. Görüşme sorularını sınamak amacıyla daha sonra araştırmaya dâhil edilmeyen 2 öğretmen ile görüşülmüş ve öğretmenlerden sorulara ve görüşmeye lişkin geri bildirim istenmiştir. Öğretmenler sorulara ve görüşmeye ilişkin olumlu geri bildirimde bulunmuşlardır.

\section{Çalışma Grubu}

Nitel araştırma yöntemlerinde amaç genelleme yapmak değil, ortaya konulan konunun derinlemesine incelenerek bir bütün oluşturma sürecidir. Amaçlı örnekleme yöntemleri nitel araştırma yöntemleri kapsamında bu doğrultuda kullanılmaktadır (Şimşek ve Yıldırım, 2011). Amaçlı örnekleme yöntemi çalışmanın amacına yönelik zengin içerikler elde edileceği durumlarda çalışma grubunun oluşturulmasında kullanılmaktadır (Patton, 2002). Amaçlı örneklemin kullanılmasında öğretmenlerin kıdemlerine göre sınıflandırılması yer almaktadır. Çalışma Kırşehir il merkezinde sosyoekonomik düzeyleri farklı okullarda görev yapan 18 okul öncesi öğretmenle yapılmıştır. Çalışmada yer alan okul öncesi öğretmenlerin kıdem yıllarına göre çalışmada 0-5 y1l arası 4 öğretmen, 5-10 yıl arası 5 öğretmen, 10-15 yıl arası 3, 15-20 yıl arası 6 öğretmen yer almıştır. Çalışmaya katılan öğretmenlerin tamamı lisans mezunudur. Bu öğretmenlerin 17'si okul öncesi lisans öğretmenliği mezunu iken 1 öğretmenin 4 yıllık çocuk gelişimi bölümünden mezun olduğu belirlenmiştir. Okul öncesi 17 öğretmenin oluşturduğu çalışma grubunun tamamını kadın öğretmenler oluşturmaktadır. Çalışmaya katılan öğretmenlerden 12'si okul öncesi öğretmenliği, 4 öğretmen çocuk gelişimi ve bir öğretmen ise açık öğretim lisans mezunudur.

\section{Veri Toplama Aracı}

Araştırmacı tarafından hazırlanmış olan "sesbilgisel farkındalık becerileri ile ilgili bilgi ve sınıf içi uygulamaları belirlemeye yönelik görüşme formu" ile araştırma verileri elde edilmiştir. Verileri elde etmek için hazırlanmış olan form iki bölümden oluşmaktadır. İlk bölümde öğretmenlerin genel bilgileri, ikinci bölümde okul öncesi öğretmenlerin sesbilgisel farkındalık kavramına yönelik bilgi ve sınıf içi uygulamalara yönelik 7 açık uçlu soru yer almaktadır. Sorular öğretmenlere tek tek yöneltilerek yanıtlar toplanmıştır. Görüşme formu kapsamında öğretmenler ile birebir görüşülerek öğretmenlerin sesbilgisel farkındalık kavramını nasıl tanımladıkları, sesbilgisel farkındalık becerilerinin gelişimleri ve düzeyleri hakkındaki bilgileri, sesbilgisel farkındalık kavramının önemi hakkında düşündükleri, çocukların sesbilgisel farkındalık bilgi ve beceri düzeylerini arttırmaya yönelik sınıf içi ne tarz etkinlikler uyguladıkları, etkinliklerin hazırlanmasında nelere dikkat ettikleri, çocukların sesbilgisel farkındalık becerilerinin değerlendirilmesinde neler yaptıkları ve bu becerilerin çocuklara kazandırılmasında yaşadıkları güçlüklerin neler olduğuna yönelik sorular sorulmuştur. Ayrıca okul öncesi öğretmenlerin genel bilgilerini elde etmek amacıyla demografik bilgi formu hazırlanmıştır. Demografik bilgi formunda okul öncesi öğretmenlerin kıdemleri, mezun oldukları lisans durumları, cinsiyetleri yer almaktadır. 


\section{Verilerin Analizi}

Nitel çalışmalarda veri analizi araştırmanın veri toplama aşamasında başlayan bir süreçtir (Creswell, 2007). Bu araştırmada temel amaç okul öncesi öğretmenlerinin sesbilgisel farkındalık kavramını öğretimine ilişkin sesbilgisel farkındalık bilgi ve becerileri, sesbilgisel farkındalık becerilerinin gelişim dönemlerini ve düzeylerini, sesbilgisel farkındalık kavramının değerlendirilmesi ve öğretim aşamasında kullanılan etkinliklerin incelenmesi, açıklanması ve yorumlanmasıdır. Görüşme formu ile elde edilen bilgiler içerik analizi yöntemi ile değerlendirilmiştir. İçerik analizi, belirli kurallara dayalı kodlamalarla yapılan niceliksel ve elde bulunan kayıtlı metinlerin çözümlenmesine yönelik bir yöntemdir (Yıldırım, 2015). Alanında uzman iki kişi bağımsız olarak yazılı kayıtları analiz ederek sorulara ilişkin temalar belirlemişlerdir. Belirlenen temalar karşılaştırılarak ortak temalar oluşturulmuştur. Araştırmanın geçerlilik ve güvenirliğinin sağlanmasında inandırıcılık (iç geçerlilik) ve transfer edilebilirlik (dış geçerlilik) ve güvenirlik ölçütleri kullanılmıştır (Merriam, 2009). Ses kayıt cihazı ile yapılan veriler değişiklik yapılmadan görüşme sırasına göre yazıya aktarılmıştır. Verilerin güvenirlik çalışması için veri analizine başlamadan önce rastgele seçilen 5 öğretmenin (verilerin \%27'si) görüşme kayıtları ve yazıya aktarımları alanında doktora eğitimini tamamlamış bir uzman tarafında doğrulanmıştır. Bu süreçte \%100 oranında bir güvenirlik elde edilmiştir. Elde edilen verilerden kategori oluşturulmuştur. Varolan bilgiler azaltma amaçlı organize edilerek kategorilere ayrılmış ve kodlanmıştır. Kesilen kodların dosyalanmasının ardından temaların oluşturulması işlemine geçilmiştir. Öğretmenlerin görüşme sırasında kullandıkları ifadeler ve verilerde yer alan bilgilere dayanarak temalar oluşturulmuştur. Araştırmacı temaları oluşturma işleminde kodlama dosyalarındaki verileri okuyarak aynı başlık altında toplayabileceği verilere birer başlık vermiş ve bu başlıklara uygun öğretmen, öğrenci ve aile konuşmalarından alıntılar yaparak verileri düzenlemiştir. Bu düzenlemeden sonra elde edilen başlıklar araştırmanın temalarını, alanında uzman 3 akademisyen ile bir araya gelerek alt başlıklar ve alt temalar oluşturmuştur. Tema oluşturma sürecinde araştırmacı tarafından 7 tema, 30 alt tema başlığı ortaya konmuştur. Geçerlilik ve güvenirlik çalışması için araştırma kapsamında oluşturulan bilgi formu ve görüşme formları için alan uzmanından görüş alınmıştır. Ayrıca görüşmelerden elde edilen veriler analiz edilerek öğretmenlere yöneltilen her bir soruya verilen yanıtlar için temalar oluşturulmuştur. Araştırmacının temalarını oluşturmasının ardından nitel araştırma konusunda deneyimli bir araştırmacı tarafından, rasgele seçilen iki kodlama dosyasıyla ilgili temalar ve alt temalar oluşturulmuştur. Daha sonra araştırmacılar bir araya gelerek yapılan kodlamaları ve belirlenen temaları karşılaştırarak tutarlılığı kontrol etmişlerdir. Araştırmacılar arasında \%95 oranında bir uyuşma sağlanmıştır. Araştırma süresince elde edilen tüm veriler ve kodlamalar, görüşme formları ve araştırmacı notları araştırmacı tarafından bir klasörde toplanmıştır.

\section{Bulgular}

$\mathrm{Bu}$ kısımda okul öncesi öğretmenlerinin görüşme formundaki her bir soruya verdikleri yanıtların analizi ayrı ayrı sunulmuştur.

\section{Sesbilgisel Farkındalık Kavramının Tanımına Yönelik Bulgular}

Tablo 1

Sesbilgisel Farkındalık Kavramının Tanımına İlişkin Öğretmen Görüşleri

\begin{tabular}{lcccccc}
\hline & $0-5$ & $5-10$ & $10-15$ & $15-20$ & $\%$ & Toplam \\
& (Kidem Y11 $)$ & (Kidem Y11 $)$ & (K1dem Y11 $)$ & (Kidem Y11 $)$ & f \\
\hline Konuşma Sesleri & 4 & 0 & 0 & 1 & 27,7 & 5 \\
Dilbilgisi Kuralları & 0 & 2 & 3 & 4 & 50 & 9 \\
Dili Doğru Kullanma & 0 & 3 & 0 & 1 & 22,2 & 4 \\
Toplam & 4 & 5 & 3 & 6 & 100 & 18 \\
\hline
\end{tabular}

0-5 arası kıdemi olan okul öncesi öğretmeni "M" sesbilgisel farkındalık kavramına ilișkin görüşlerini "Sesbilgisel farkındalık insanların konuşma esnasında çıkardıkları seslerle ilgili bir 
durumdur" sözleri ile ifade etmektedir. 5-10 arası kıdemi olan okul öncesi öğretmeni "F" sesbilgisel farkındalık kavramına ilişkin görüşlerini belirtirken şu ifadeleri kullanmıştır: "Çocuklar sesleri bildiklerinde ve farkında olduklarında dili iyi kullanmaktadirlar bunun adı alanda sesbilgisel farkındalık olarak geçmektedir". 10-15 arası kıdemi olan okul öncesi öğretmeni "B" sesbilgisel farkındalık kavramına ilişkin görüşlerini "Okul öncesi dönemde çocukların kazanmaları gereken dil bilgisi kurallarıdır ve bu dil bilgisi kurallarını edinmeden ilkokula başladıklarında okuma öğrenmede zorluk yaşamaktadırlar". 15-20 arası kıdemi olan okul öncesi öğretmeni "G" ise sesbilgisel farkındalık kavramına ilişkin görüşlerinde şu ifadeleri kullanmıştır: "Çocukların doğduktan şimdiki zamana kadar geçen cümle yapılarını öğrenmesi, sözcük dağarcı̆̆l ve dille ilgili herşey" şeklinde ifade etmiştir. Genel olarak bakıldığında öğretmenlerin sesbilgisel farkındalık kavramını bilmedikleri bununla birlikte kavramı yanlış kullandıkları tespit edilmiştir.

Görüşme yapılan öğretmenlerin görüşleri değerlendirildiğinde "sesbilgisel farkındalık kavramını nasıl tanımlarsınız?" sorusuna verilen cevaplarda sesbilgisel farkındalık kavramını alan yazında yer alan tanımı ile bilmedikleri görülmüştür. Nasıl tanımladıklarına ilişkin soruya verilen yanıtlarda ise 5 öğretmen konuşma ile ilgili olduğunu, 9 öğretmen dilbilgisi kuralları olduğunu, 4 öğretmen ise dili doğru kullanma olarak tanımlamışlardır. Öğretmenlerden alınan yanıtların ardından sesbilgisel farkındalık kavramı açıklanmıştır. 12 öğretmen sesbilgisel farkındalık kavramının içeriğini bildiğini dile getirmiş fakat alan yazında kullanılan ismini bilmedikleri belirlenmiştir. Genel olarak bakıldığında okul öncesi öğretmenlerinin sesbilgisel farkındalık kavramını bilmedikleri tespit edilmiştir.

\section{Sesbilgisel Farkındalık Becerilerinin Gelişimine Yönelik Bulgular}

Tablo 2

Sesbilgisel Farkındalık Becerilerinin Gelişimine İlişkin Öğretmen Görüşleri

\begin{tabular}{|c|c|c|c|c|c|c|}
\hline & $\begin{array}{c}0-5 \\
\text { (K1dem } \\
\text { Y1li) } \\
\text { f } \\
\end{array}$ & $\begin{array}{c}\text { 5-10 } \\
\text { (K1dem Y1li) } \\
\mathrm{f}\end{array}$ & $\begin{array}{c}10-15 \\
\text { (K1dem Y1l1) } \\
f\end{array}$ & $\begin{array}{c}15-20 \\
\text { (K1dem Y1li) } \\
\text { f }\end{array}$ & $\%$ & $\begin{array}{c}\text { Toplam } \\
\text { F }\end{array}$ \\
\hline Yaşa Bağlı Gelişim & 2 & 4 & 3 & 3 & 66,6 & 12 \\
\hline Doğuștan Gelen ve Kendiliğinden Gelișen & 0 & 0 & 3 & 2 & 27,7 & 5 \\
\hline İşitsel Gelişimle İlgili & 2 & 1 & 0 & 1 & 22,2 & 4 \\
\hline Toplam & 4 & 5 & 3 & 6 & 100 & \\
\hline
\end{tabular}

0-5 arası kıdemi olan okul öncesi öğretmeni "L" sesbilgisel farkındalık becerilerinin gelişimlerine ilişkin görüşlerini "Çocukların yaşları büyüdükçe sesbilgisel farkindalık gelişmektedir" sözleri ile ifade etmektedir. 5-10 arası kıdemi olan okul öncesi öğretmeni "Y" sesbilgisel farkındalık becerilerinin gelişimlerine ilişkin görüşlerini belirtirken şu ifadeleri kullanmıştır: "Yaşa bağlı olarak her beceri gelişimi gibi ilerlemekte olduğunu düşünüyorum fakat hangi yaş ve gelişim dönemlerinde neleri kapsadığını bilmiyorum". 10-15 arası kıdemi olan okul öncesi öğretmeni "B" sesbilgisel farkındalık kavramına ilişkin görüşlerini "Gelişime yönelik herhangi bir süreç izlememekteyim çünkü bazı beceriler kendiliğinden doğal akışında gerçekleşmektedir". 15-20 arası k1demi olan okul öncesi öğretmeni "G" ise sesbilgisel farkındalık kavramına ilişkin görüşlerinde şu ifadeleri kullanmıştır: "Çocukların işitsel algıları geliş̧ikçe sesbilgisel farkındalık becerileride gelişecektir ve bu çocuk için önemlidir" şeklinde ifade etmiştir. Öğretmenlerin yaşa bağlı olduğunu belirtmişlerdir ancak hangi yaş grubunda nasıl gelişme göstermekte ya da becerilerin gelişim sıraları ile ilgili bilgileri olmadığ 1 tespit edilmiştir. Ayrıca öğretmenlerin verdikleri yanıtlardan sesbilgisel farkındalık becerilerinin neler olduğunu belirten ve isimlerini kullanan bir öğretmen olmamıştır.

Öğretmenlere yöneltilen "sesbilgisel farkındalık becerilerinin gelişimi ve sesbilgisel farkındalık becerilerin düzeylerini nasıl açıklarsınız?" sorusuna 12 öğretmen yaş ile birlikte geliştiğini, 5 öğretmen ise kendiliğinden geliştiğini, 4 öğretmende işitsel bir gelişim olduğunu belirtmişlerdir. Çalışmaya katılan okul öncesi öğretmenlerinin sesbilgisel farkındalık becerilerinin gelişimleri ve bu becerilerin gelişim düzeyleri hakkında bilgi sahibi olmadığı tespit edilmiştir. 


\section{Sesbilgisel Farkındalık Kavramının Önemine Yönelik Bulgular}

Tablo 3

Sesbilgisel Farkındalık Kavramının Önemine İlişkin Öğretmen Görüşleri

\begin{tabular}{|c|c|c|c|c|c|c|}
\hline & $\begin{array}{c}0-5 \\
\left(K_{1 d e m} Y_{1} l_{1}\right) \\
f\end{array}$ & $\begin{array}{c}\text { 5-10 } \\
\text { (Kıdem Y1lı) } \\
\mathrm{f}\end{array}$ & $\begin{array}{c}10-15 \\
\text { (Kidem Y1li) } \\
\mathrm{f}\end{array}$ & $\begin{array}{c}15-20 \\
\text { (K1dem Y1lı) } \\
\text { f }\end{array}$ & $\%$ & $\begin{array}{l}\text { Toplam } \\
\text { F }\end{array}$ \\
\hline Okuma Yazma İçin Önemli & 3 & 4 & 2 & 3 & 66,6 & 12 \\
\hline Dil ve Konuşma İçin Önemli & 1 & 1 & 1 & 3 & 33,3 & 6 \\
\hline Toplam & 4 & 5 & 3 & 6 & 100 & 18 \\
\hline
\end{tabular}

0-5 arası kıdemi olan okul öncesi öğretmeni "M" sesbilgisel farkındalık kavramına önemine ilişkin görüşlerini "Çocuklar bu becerileri kazanırsa ilerleyen dönemde okuma alanında başarı gösterecektir." sözleri ile ifade etmektedir. 5-10 arası kıdemi olan okul öncesi öğretmeni "F" sesbilgisel farkındalık kavramının önemine ilişkin görüşlerini belirtirken şu ifadeleri kullanmıştır: "Çocukların harfleri doğru öğrenmelerinde gerekli olmaktadır. Sesbilgisel farkındalı çocukta olmaz ise harfleri doğru birleştiremez ve okuyamaz". 10-15 arası k1demi olan okul öncesi öğretmeni "B" sesbilgisel farkındalık kavramına ilişkin görüşlerini "Çocuklar eğerki bu becerileri edinemezse okuma sürecinde okuduğunu anlamayı geliştirememektedir. Bu yüzden okuma için önemlidir". 15-20 arası kıdemi olan okul öncesi öğretmeni " $G$ " ise sesbilgisel farkındalık kavramına ilişkin görüşlerinde şu ifadeleri kullanmıştır: "Sesbilgisel farkındalı becerileri çocuklarda yoksa konuşmada zorluk yaşayacaktır ve okumada harfleri doğru telaffuz edemeyecektir" şeklinde ifade etmiştir. Genel olarak bakıldığında öğretmenlerin sesbilgisel farkındalık kavramını, becerilerin isimlerini ve içeriklerini, gelişimlerini bilmedikleri görülmekle birlikte öğretmenlerin genelinin önemine ilişkin sorulan soruda okuma ile ilgili olduğunu ve okuma başarısı için önemli bir beceri olduğunu vurgulamışlardır.

"Sesbilgisel farkındalık kavramının önemi hakkında düşünceleriniz nelerdir?" sorusuna 12 öğretmen çocuklar formal olarak okuma yazmaya öğrenimine başladıklarında daha önceden edinilmiş olan sesbilgisel farkındalık becerilerinin onların okuma yazma alanında ve akademik başarılarında önemli bir role sahip olduğunu belirtmişleridir. 6 öğretmen ise sesbilgisel farkındalık kavramının dil konuşma alanlarında çocuklar için önemli olduğundan söz etmiş̧lerdir.

\section{Sesbilgisel Farkındalık Becerileri Etkinliklerine ve Etkinliklerin Hazırlanmasında Dikkat Edilen Hususlara Yönelik Bulgular}

Tablo 4

Sesbilgisel Farkındalık Becerileri Etkinliklerine ve Etkinliklerin Hazırlanmasında Dikkat Edilen Hususlara İlişkin Öğretmen Görüşleri

\begin{tabular}{|c|c|c|c|c|c|c|}
\hline & $\begin{array}{c}0-5 \\
\text { (K1dem } \\
\text { Y1li) } \\
\text { f } \\
\end{array}$ & $\begin{array}{c}5-10 \\
\text { (K1dem } \\
\text { Y111) } \\
\text { f } \\
\end{array}$ & $\begin{array}{c}10-15 \\
\text { (K1dem } \\
\text { Y1li) } \\
\text { f }\end{array}$ & $\begin{array}{c}15-20 \\
\text { (Kidem } \\
\text { Y111) } \\
\text { f }\end{array}$ & $\%$ & $\begin{array}{c}\text { Toplam } \\
\text { F }\end{array}$ \\
\hline \multicolumn{7}{|l|}{ Etkinlik Çeşitleri } \\
\hline Ses Ekleme & 2 & 0 & 0 & 0 & 11,1 & 2 \\
\hline Farklı Kelimeler Oluşturma & 0 & 1 & 0 & 0 & 5,5 & 1 \\
\hline Aynı Sesle Başlayan Kelimeler & 0 & 1 & 0 & 0 & 5,5 & 1 \\
\hline Hikâye Anlatımı & 0 & 1 & 0 & 2 & 16,6 & 3 \\
\hline Bilmece ve Parmak Oyunları & 1 & 0 & 0 & 2 & 16,6 & 3 \\
\hline Sesli Harf Öğretimi ve Yazı Çalışmaları & 0 & 2 & 0 & 2 & 22,2 & 4 \\
\hline Müzik Uygulamaları & 1 & 0 & 3 & 0 & 22,2 & 4 \\
\hline Toplam & 4 & 5 & 3 & 6 & 100 & 18 \\
\hline
\end{tabular}

Etkinliklerin Oluşturulmasını Dikkat

Edilen Hususlar

\begin{tabular}{llllllr}
\hline Yaş ve Bilişsel Seviye & 1 & 4 & 2 & 2 & 50 & 9 \\
Motor Gelişimler & 2 & 0 & 0 & 0 & 11,1 & 2 \\
Sürdürülebilirlik & 0 & 1 & 0 & 0 & 5,5 & 1 \\
Basitten Zora & 0 & 0 & 1 & 0 & 5,5 & 1
\end{tabular}


Sosyoekonomik Durum

Gömülü Öğretime

Toplam

$\begin{array}{cccccc}1 & 0 & 0 & 1 & 11,1 & 2 \\ 0 & 0 & 0 & 3 & 22,2 & 3 \\ 4 & 5 & 3 & 6 & 100 & 18\end{array}$

0-5 arası kıdemi olan okul öncesi öğretmeni "Ç" sesbilgisel farkındalık becerilerine yönelik etkinlikler ve etkinliklerin hazırlanmasınada dikkat edilen hususlara ilişkin görüșlerini "Sesbilgisel farkındalı̆̆a ilișkin ses çalıșmaları yapmaktayım örneğin bir kelimeye ses ekleme çalıșmaları yapmaktayım. Bu etkinlikleri hazırlamada çocukların yapabileceği daha doğrusu bildiği kelimeler üzerinden hareket etmekteyim" sözleri ile ifade etmektedir. 5-10 arası kıdemi olan okul öncesi öğretmeni "Ş" sesbilgisel farkındalık becerilerinin gelişimlerine ilişkin görüşlerini belirtirken şu ifadeleri kullanmıştır: "Okuma çalışmlarına okul öncesi siteri takip etmekteyim ve orada farkl kelime oluşura bilme çalışmalarını, yazı çalışmalarını almaktayım”. 10-15 arası kıdemi olan okul öncesi öğretmeni "B" sesbilgisel farkındalık kavramına ilişkin görüşlerini "Çocukları sıkmadan vermek istediğim vey kazandırmak istediğim davranışları onlara hissettirmeden oyun içinde kurgulamaktayım. Tekerleme müzik uygulamalarını bu iş için sıklıkla kullanmaktayım". 15-20 arası kıdemi olan okul öncesi öğretmeni "G" ise sesbilgisel farkındalık kavramına ilişkin görüşlerinde şu ifadeleri kullanmıştır: "Çocukların seslere odaklanmalarından bol seslemeli hikâye kitapları okumaktayım ve çocukların ses ayrımını güçlendiriyorum" şeklinde ifade etmiştir.

Genel olarak bakıldığında öğretmenlerin her bir beceriye ayrı ayrı odaklanmadıkları, sadece internet ortamlarında takip ettikleri bazı sitelerden alıp kullandıkları etkinliklerin içeriğinde kısmen sesbilgisel farkındalık becerilerine yönelik olduğu görülmüştür. Öğretmenlere sesbilgisel farkındalık becerilerine yönelik ne tarz etkinlikler oluşturduklarına ve bu etkinliklerinin geliştirilmesinde nelere dikkat ettikleri sorulduğunda, 2 öğretmen kelimelere ses ekleme çalışmaları yaptırdıklarını, 1 öğretmen kelimelere yeni sesler ekleyerek farklı kelimeler oluşturduklarını, 1 öğretmen aynı sesle başlayan kelimeleri buldurmaya yönelik etkinlikler yaptırdıklarını belirtmişleridir. 3 öğretmen hikâye anlattıklarını, 3 öğretmen bilmece ve parmak oyunları yaptırdıklarını, 4 öğretmen alfabe öğretimi (sesli harfler) ve yazı çalışmaları yaptırdıklarını ve 4 öğretmen ise müzik uygulamaları yaptırdıklarını belirtmişleridir. 9 öğretmen etkinliklerin hazırlanmasında çocukların yaşlarına ve bilişsel seviyelerine dikkat ettiklerini belirtmişleridir. Ayrıca 2 öğretmen çocukların motor beceri gelişimlerine, 1 öğretmen etkinliklerin sürdürülebilirliğine, 1 öğretmen basitten zora giden bir yol izlediğini, 2 öğretmen çocukların sosyoekonomik durumuna, 3 öğretmen ise uyguladıkları etkinliklerde gömülü öğretimle vermeye çalıştıklarını belirtmişlerdir.

\section{Sesbilgisel Farkındalık Becerilerin Değerlendirilmesine Yönelik Bulgular}

Tablo 5

Sesbilgisel Farkındalık Becerilerin Değerlendirilmesine İliskin Öğretmen Görüsleri

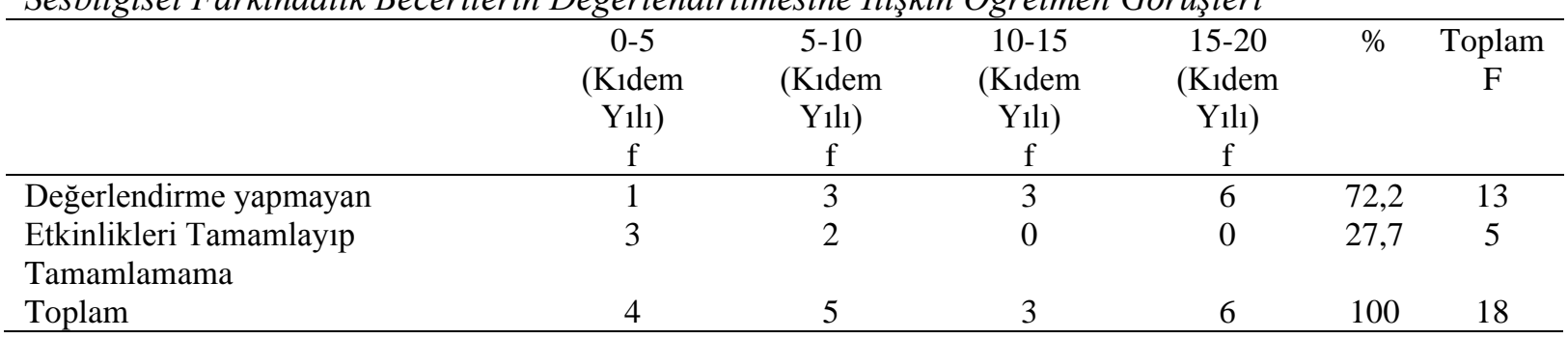

0-5, 5-10, 10-15 ve 15-20 arası kıdemi olan okul öncesi öğretmenlerin büyük çoğunluğu sesbilgisel farkındalık becerilerine yönelik değerlendirme sürecine yapmadıklarını belirtmişler ve " $\mathrm{R}$ " öğretmen "Sinıfimda değerlendirmede çocukları sadece gözlemlerim ve eksiklerini tespit etmeye çalışırım ama sesblgisel farkındalı̆̆a ilişkin bir değerlendirme kâ̆ğt veya gözlemler yapmadım" sözleri ile ifade etmektedir. Genel olarak bakıldığında öğretmelerin sınıflarında sesbilgisel farkındalık becerilerine yönelik ayrıntılı bir değerlendirme yapmadıkları tespit edilmiştir. Sadece kurguladıkları etkinlikleri çocukların bitirip bitirmediklerine bakarak değerlendirme yaptıkları ve bu değerlendirme sürecinde de sesbilgisel farkındalık becerilerine yönelik bir değerlendirme yapmadıkları tespit edilmiştir. Okul öncesi öğretmenlere sesbilgisel farkındalık becerilerin değerlendirilmesinde neler 
yaptıkları sorulduğunda 12 öğretmen değerlendirme yapmadıklarını, 5 öğretmen etkinliği tamamlayıp tamamlamadıklarına göre değerlendirme yaptıklarını belirtmişlerdir.

\section{Sesbilgisel Farkındalık Becerilerin Çocuklara Kazandırılması Aşamasında Karşılaşılan Sorunlara Yönelik Bulgular}

Tablo 6

Sesbilgisel Farkındalık Becerilerin Çocuklara Kazandırılması Aşamasında Karşılaşılan Sorunlara Illişkin Öğretmen Görüşleri

\begin{tabular}{|c|c|c|c|c|c|c|}
\hline & $\begin{array}{c}0-5 \\
\text { (Kidem } \\
\text { Y111) }\end{array}$ & $\begin{array}{c}5-10 \\
\text { (Kidem } \\
\text { Y1li) }\end{array}$ & $\begin{array}{c}10-15 \\
\text { (Kidem } \\
\text { Y1li) }\end{array}$ & $\begin{array}{c}15-20 \\
\text { (K1dem } \\
\text { Y1li) }\end{array}$ & $\%$ & $\begin{array}{c}\text { Toplam } \\
\text { F }\end{array}$ \\
\hline & $\mathrm{f}$ & $\mathrm{f}$ & $\mathrm{f}$ & $\mathrm{f}$ & & \\
\hline Bireysel Farklılıkların Olması & 3 & 3 & 3 & 4 & 72,2 & 13 \\
\hline Etkinliklerinin Seviyesi & 1 & 0 & 0 & 1 & 11,1 & 2 \\
\hline Etkinliklere Katılmada İsteksizlik & 0 & 1 & 0 & 1 & 11,1 & 2 \\
\hline $\begin{array}{l}\text { Yetersizliği Olan Çocuklarda } \\
\text { Yasanan Zorluk }\end{array}$ & 0 & 1 & 0 & 0 & 5,5 & 1 \\
\hline Toplam & 4 & 5 & 3 & 6 & 100 & 18 \\
\hline
\end{tabular}

0-5 arası kıdemi olan okul öncesi öğretmeni "L" sesbilgisel farkındalık becerilerinin gelişimimlerine ilişkin görüşlerini "Çocukların bireysel farklılıklarından dolayı beceri kazandırmada her biri için ayrı etkinlik hazırlamak zor olmaktadır" sözleri ile ifade etmektedir. 5-10 arası kıdemi olan okul öncesi öğretmeni "Y" sesbilgisel farkındalık becerilerinin gelişimlerine ilişkin görüşlerini belirtirken şu ifadeleri kullanmıştır: "Gelişimsel olarak yetersizliği olan çocuklarda bu becerilerin kazanımı yetersizliklerinden dolayı zorlaşmaktadır". 10-15 arası kıdemi olan okul öncesi öğretmeni "B" sesbilgisel farkındalık kavramına ilişkin görüşlerini "Sinıfimdaki iyi çocuk ile kötü çocuk arasında bireysel fark olması dersi etkin işlememe engel olmaktadır". 15-20 arası kıdemi olan okul öncesi öğretmeni "G" ise sesbilgisel farkındalık kavramına ilişkin görüşlerinde şu ifadeleri kullanmıştır: "Çocuklar yapılan etkinlikten keyif almıyor ise o etkinliğe katılmıyor tekrar çocuğu etkinliğe dâhil etmek zor oluyor" şeklinde ifade etmiştir. Genel olarak bakıldığında öğretmenler çocuklara sesbilgisel farkındalık becerilerinin kazandırılmasında bireysel farklılıklardan kaynaklı zorluklara değinmişlerdir. Ancak daha önceki bulgular 1şı̆̆ında bakıldığında öğretmenlerin bu konuda yetersiz olmaların sesbilgisel farkındalık kavramına ve içeriğine ilişkin bilgilerinin olamaması sesbilgisel farkındalık becerilerilerin etkin bir şekilde kazandırılılamamasında etkili olmaktadır.

Okul öncesi öğretmenlerin 13'ü çocukların bireysel farkl1lıklarının olmasının sesbilgisel farkındalık kavramların çocuklara kazandırılmasında zorluğa neden olduğunu belirtmişlerdir. Ayrıca 2 öğretmen etkinliklerin seviyelerinin bazı çocuklar için zor veya kolay olmasının çocuklara bu becerilerin kazandırılmasında etkili olduğunu belirtmişlerdir.

\section{Sonuç, Tartışma ve Öneriler}

Bu çalışmada okul öncesi öğretmenlerinin sesbilgisel farkındalık bilgi düzeyleri ve sınıf içi uygulamalarına yönelik görüşleri incelenmiştir. Araştırmadan elde edilen bilgiler alanyazın kapsamında ve araştırma soruları temelinde tartışılmıştır.

Elde edilen bulgulara bakıldığında ilk olarak, sesbilgisel farkındalık kavramının okul öncesi öğretmenleri tarafından "Konuşma Sesleri, Dilbilgisi Kuralları, Dili Doğru Kullanma" olarak tanımlandığı görülmüsştür. Okul öncesi öğretmenleri tarafından yapılan bu tanımlarda öğretmenlerin sesbilgisel farkındalık kavramını şeklinde kavramsallaştırdıkları görülmektedir. Okuma başarısı için önemli bir yere sahip olan sesbilgisel farkındalık kavramının (Apel ve Lawrence, 2011; Hogan, Catts ve Little, 2005; Lonigan, Burgeess ve Anthony, 2000; Schatschneider, Fletcher, Francis, Carlson ve Foorman, 2004; Torgesen, Wagner ve Rashotte, 1994) okul öncesi öğretmenler tarafından bilinmediği görülmüştür. Bu sonucun ortaya çıkmasında alanyazına ilişkin yanlış anlaşılmalar yer almaktadır. Pek 
çok öğretmen sesbilgisel farkındalığı sesleri çözümleye bilme, dilbilgisi kuralları gibi terimler için kullanılan yeni bir kavram olduğuna inanmaktadır (Bueno, Darling-Hammond ve Gonzales, 2010; Yopp ve Yopp, 2009). Sesbilgisel farkındalık becerileri açısından yeterli bilgi ve donanıma sahip olan öğretmenler çocukların sesbilgisel farkındalık becerilerini geliştirmeye yönelik eğitimlerde önemli rol üstlenmektedir (Withrow, 2014). Sesbilgisel farkındalık eğitiminin başlıca zorluklarından birisi, yeni ve eski öğretmenlerin aldıkları eğitimdir (Barnett vd., 2015). Öğretmenlerin formal eğitimleri, mesleki gelişimleri ve yaşantısal öğrenimleri sırasında aldıkları sesbilgisel farkındalığı öğretme anlayışı ve kullandıkları yöntemlere bakıldığında, bunlar yenilikçi eğitim programları ile tutarlılık göstermemekte, bu da öğretimin yeterliliği ile çocuğun öğrenmesini etkilemektedir (Chu vd., 2010). $\mathrm{Bu}$ açıdan bakıldığında çocukların sesbilgisel farkındalık becerilerinin gelişmesinde önemli bir rol üstlenen öğretmenlerin sesbilgisel farkındalık becerilerine yönelik yeterli bilgilere sahip olması gerekmektedir. Güldenoğlu, Kargın ve Ergül (2016) yılında yaptıkları çalışmada öğretmenlerin sesbilgisel farkındalık alanında yetkin olması gerektiğini çünkü okuduğunu anlama ile doğrudan ilişkili olan bu becerinin çocuklara kazandırılmasının önemli olduğunu ve bunu sağlayacak öğretmenerlin ise bu alanda gerekli donanıma sahip olması gerektiğini vurgulamışlardır. Bu görüşten hareketle, okuma becerisinin temellerinin oluşturulduğu okul öncesi eğitim kapsamında sesbilgisel farkındalık becerilerin öğretimine yer verilmesinin önemle üzerinde durulması gereken bir konu olduğu ve öğrencilerin ileride sahip olacakları genelde akademik, özelde okuma becerileri için alanda çalışan okul öncesi öğretmenlerine büyük işlerin düştüğ̈̈ görülmektedir. Bu açıdan bakıldığında alanda çalışan öğretmenlerin, okuma ve okumaya hazırlık çalışmaları sırasında öncelikle öğrencilerin sahip oldukları sesbilgisel bilgi ve becerilerini doğru betimlemeleri ve bu becerilerde sınırlılıkları olan öğrenciler için öncelikle uygun eğitim içeriklerini düzenlemeleri gerektiği düşünülmektedir.

Sesbilgisel farkındalık kavramının tanımına ilişkin yöneltilen soruda elde edilen bir diğer bulguda öğretmenlerin kavramın ismine yönelik bilgilerinin olmadığı tespit edilmiştir. Ancak sesbilgisel farkındalığın önemine yönelik öğretmenlere yöneltilen soruda öğretmenlerin çoğunluğu sesbilgisel farkındalığın formal okumaya yazma öğrenimine başlamadan önce edinilmiş olan sesbilgisel farkındalık becerilerinin onların okuma yazma alanında ve akademik başarılarında önemli olduğunu vurgulamışlardır. Sesbilgisel farkındalık becerileri erken okuryazarlık becerileri içerisinde okumay1 en güçlü şekilde yordayan becerilerden biridir (Kjeldsen, Kärnä, Niemi, Olofsson ve Witting, 2014; Rakhlin, Cardoso-Martins ve Grigorenko, 2014). Birçok çalışmada, sesbilgisel farkındalık ile okuma arasında anlamlı bir ilişki olduğu ve erken dönemde yeterli sesbilgisel farkındalık becerilerine sahip olan çocukların, ileriki okuma ve okuduğunu anlama performanslarının yeterli olmayan akranlarına göre daha iyi olacağının vurgulandığı görülmektedir (Babayiğit ve Stainthorp, 2007; Lundberg, Frost ve Petersen, 1988; Maclean, Bryant ve Bradley, 1987; Nathan, Stackhouse, Goulandris and Snowling, 2004; Yeh ve Connell, 2008).

Çalışma içerisinde yer alan sesbilgisel farkındalık becerilerinin gelişimi ve sesbilgisel farkındalık becerilerin düzeylerine yönelik öğretmenlere sorulan bir diğer soruya yönelik sonuçlara bakıldığında bu becerilerin "yaş ile birlikte, doğal olarak ve işitsel bir gelişime" gösterdiğine dair öğretmenlerden yanıtlar alınmıştır. Okuma başarısı için önemli olan sesbilgisel farkındalık becerilerinin gelişim aşamalarına ve düzeylerine yönelik öğretmenlerin bilgilerinin olmadıkları düşünülmektedir. Okul öncesi dönemde hızla ortaya çıkmakta ve gelişmek göstermekte olan bu becerilerin (Webb, Schwanenflugel ve Kim, 2004) gelişim süreçleri ve düzeylerinin öğretmenler tarafından bilinmesi gerekmektedir (Guimaraes ve Youngman, 1995). Öğretmenlerin bu becerilerin gelişimlerine hâkim olmaları sesbilgisel farkındalık becerilerin çocuklara kazandırılmasında önemli bir yer tutmaktadır (Landry, Anthony, Swank ve Monseque-Bailey, 2009). Çünkü sesbilgisel farkındalık becerileri ilk olarak heceleri ayırma, ardından uyak farkındalığı daha sonra ise kelimelerin ilk sesleri ve son sesleri hakkında bir farkındalık düzeyine doğru sıralama izler. Sesbilgisel farkındalık becerileri gelişmeye devam ettikçe seslerin yerlerini değiştirme, kelimeleri seslerine ayırma becerilerine sahip olurlar ve son olarak, kelimelerdeki sesleri atma ve kelimelerdeki seslerin yerlerini değiştirme becerilerine kadar gelişme devam eder. Bu durum sesbilgisel farkındalık becerilerinin daha az karmaşık olan yapılardan daha karmaşık yapılara doğru bir zorluk sırası izlediğini göstermektedir (Schuele, Skibbe ve Rao, 2007). Erken dönemde, sesbilgisel farkındalık alanında okulda geliştirilen çalışmalar, okuma ve yazma görevlerinde başarısız olmayı engelleyerek 
okul başarısını güçlendirecektir (Ferraz, Pocinho, Pereira ve Pimenta, 2015) bunu sağlayacak olan kişiler ise öğretmenlerdir (Koutsoftas, Harmon ve Gray, 2009).

Okul öncesi dönemde çocukların sesbilgisel farkındalık becerilerine yönelik etkinlikler ile karşılaşmak çocukların okuma için gereken ön koşul becerileri kazanmalarında (Ong, 2008) ve ilerideki okuma başarısının güçlü bir yordayıcısıdır (Bradley ve Bryant, 1983; Lundberg, Olofsson ve Wall, 1980; Torgeson vd., 1994) önemlidir. Yapılan analizler sonucunda öğretmenlerin sesbilgisel farkındalık becerilerine için ne tarz etkinlikler oluşturdukları ve bu etkinliklerinin geliştirilmesinde nelere dikkat ettikleri yönelik sorulan soruda "kelimelere ses ekleme, ilk sesleri aynı olan kelimeleri bulma çalışmaları yaptırdıkları aynı zamanda hikâye anlatımları, bilmece oyunları, parmak oyunları ve alfabede yer alan sesli harflerin öğretimini yaptıklarını belirtmişlerdir”. Okul öncesi öğretmenlerin uyguladıkları etkinliklerin sesbilgisel farkındalık becerilerinin kazandırılmasında yetersiz olduğu düşünülmektedir. Ayrıca öğretmenlerin sesbilgisel farkındalık becerilerine yönelik oluşturdukları etkinliklerde sesbirimsel farkındalık becerilerine yönelik etkinlik tasarladıkları fakat sesbilgisel farkındalık beceri içerisinde yer alan diğer beceri alanlarına yönelik bir etkinlik oluşturmadıkları görülmektedir. Ayrıca sesbilgisel farkındalık becerilerine yönelik yaptıkları etkinliklerin birçoğunun sesbilgisel farkındalık becerilerine yönelik değil erken okuryazarlık becerileri içerisinde yer alan yazı farkındalı̆̆ , dinlediğini anlama, sözcük bilgisi ve harf bilgisine yönelik olduğu görülmüştür. Alan yazın kapsamında bu bulguya bakıldığında, sesbilgisel farkındalık becerileri için en çok odaklanılan beceriler içerisinde yer alan uyak farkındalığ 1 , hece ve kelime farkındalığ 1 , sesbirimsel beceriler yer almaktadır (Gillon, 2002). Bu becerilerin her birine yönelik etkinlikler sesbilgisel farkındalık becerilerinin kazandırılmasında uygulanmalıdır (Hsin, 2017). Sesbilgisel farkındalık becerilerine yönelik geliştirilen etkinliklerin hazırlanmasında öğretmenlerin "çocukların yaşlarına, bilişsel seviyelerine, motor gelişimlerine, basitten zora giden bir sıraya, etkinliklerin sürdürülebilirliğine" dikkat ettikleri bulgusuna ulaşılmıştır. Bu durum öğretmenlerin sesbilgisel farkındalık becerilerine yönelik etkinliklerin hazırlanmasında öğrenim yapılacak olan grubun özelliklerine (küçük veya büyük grup) (Robinson, 2010), uygulanacak etkinliklerin uygulanma yöntemlerine (Robinson, 2013), etkinliklerin sistematik ve açıklı̆̆ına (Jaskolski, 2013), içeriklerinin hazırlanması ile ilgili bilgilere (sürekli seslerin söylenişlerini uzatarak ve süreksiz sesleri de tekrar ederek, hedef kelimenin parça özelliklerinin yapısı kurulması, etkinliklerin uygulanmasında sıralamayı, parçalara ayırmayı ve birleştirmeyi kolaylaştırmak için yönlendirici) (Trio, 2004) dikkat etmedikleri tespit edilmiştir. Ülkemizde Emir, Girgin ve Karasu (2015) yılında öğretmenlerin sesbilgisel farkındalık becerilerine yönelik oluşturulan etkimliklerin kullanılma sıklıklarına ilişkin yaptıkları çalışmada öğretmenelrin yeterli sıklıkta sesbilgisel farkındalık etkinlikleri kullanmadıkları tespit etmişlerdir. Ayrıca öğretmenerlin zayıf sesbilgisel farkındalığa sahip olan öğrencilerin eğitimlerinde etkinliklere daha az yer veriklerini belirlemişlerdir. Buyüzden başarılı bir sesbilgisel farkındalık eğitimi için etkinliklerin yukarıda bahsedilen unsurlara odaklanması gerektiği alan yazında belirtilmektedir.

Okul öncesi dönemdeki çocuklarda yer alan sesbilgisel farkındalık becerilerinin değerlendirilmesinde kullandıkları yöntemler öğretmenlere sorulduğunda çoğunun değerlendirme yapmadığı bir kısım öğretmenin ise çocukların etkinlikleri tamamlayıp tamamlamadıklarına göre değerlendirme yaptıkları görülmüştür. Elde edilen bu bulguyu açıklamak için alan yazına bakıldığında, bir alana özgü değerlendirme ve öğretim birbirinden ayrı düşünülemez; çünkü değerlendirme süreci öğretime rehberlik eder. Bir çocuğun sesbilgisel farkındalık becerilerinin gelişiminin değerlendirilmesinde bir tek yöntem uygun değildir. Sesbilgisel farkındalık becerileri içerisinde yer alan tüm beceri alanları ayrı değerlendirilmelidir (Fridriksson, Moser, Bonilha ve Morrow, 2007). Okul öncesi öğretmenlerin sesbilgisel farkındalık becerilerine yönelik değerlendirmeyi sadece süreç olarak yaptıkları çocukların durumlarına yönelik değerlendirme yapmadıkları gözlenmekte, etkinlikleri tamamlayıp tamamlamamalarına göre değerlendirme yapan öğretmenlerin de bir ölçüt kullanmadıkları görülmüştür.

Sesbilgisel farkındalık becerilerin kazandırılmasında öğretmenlerin karșılaștıkları sorunlara ilişkin sonuçlara bakıldığında, çocukların bireysel farklılıklarından kaynaklanan sesbilgisel farkındalık becerilerinin çocuklara kazandırılmasında zorlukla karşılaştıkları görülmektedir. Ayrıca uyguladıkları etkinlik seviyelerinin bazı çocuklar için zor olmasının sesbilgisel farkındalık becerilerinin 
kazandırılmasında yaşanılan sorunlar arasında belirtilmiştir. Alan yazın kapsamında bu sonuca bakıldığında; kapsamlı, sistematik ve kuramsal temelli etkili bir müdahale programının olmaması öğretim ortamlarında öğretmenlerin çocuklara sesbilgisel farkındalık becerileri edindirmesinde ciddi güçlükler yaşamalarına neden olmaktadır (Akdal, 2018). Çocukların sesbilgisel farkındalık kavramına yönelik farklı düzeylerde olmaları karşılaşılan bir sorun olarak sesbilgisel farkındalık kavramının edindirilmesinde zorluk olarak belirlenmektedir. $\mathrm{Bu}$ zorlukların giderilmesi için uygulanan etkinliklerin öğretim yöntemlerinde farklılaşması gerektiği vurgulanmaktadır (Yopp ve Yopp, 2009). Öğretmenlerin sesbilgisel farkındalık becerilerini destekleyen etkinliklere sınırlı sayıda yer verdikleri ve sesbilgisel farkındalık becerileri hakkında yeterli bilgiye sahip olmadığı vurgulanmaktadır (Bos, Mather, Dickson, Podhajski ve Chard, 2001).

Türkiye'de erken okuryazarlık alanına yönelik yapılmış çalışmalara bakıldığında sesbilgisel farkındalık alanına yönelik çalışmalar olduğu bununla birlikte eksikliklerinde yeraldığı görülmektedir ve çalışmaların yeni yeni hız kazanmaya başladığı görülmektedir. İlerleyen yıllarda sesbilgisel farkındalık becerilerinin edinilmesinde uygulanan müdahale programlarının, öğretmen yeterliliklerinin, etkinlik içeriklerinin ve değerlendirilmesine yönelik çalışmaların sayısının artacağı ve daha derinlemesine incelemelerin olacağı düşünülmektedir. Bu çalışmada ortaya konan sonuçlar okul öncesi programlarının hazırlanmasına yönelik bilgiler sunmaktadır. Okul öncesi programların hazırlanmasında sesbilgisel farkındalık tüm yönleri ile programa dâhil edilmelidir. Programda yer alan kavramlara ve kazandırılması istenen becerilere yönelik alan okul öncesi öğretmenlere hizmet içi eğitimler verilmesi çocukların okul öncesi dönemde kritik beceriler içerisinde yer alan sesbilgisel farkındalık becerilerinin edinimine katkı sağlaması açısından önemlidir. Eğitim fakültelerinin okul öncesi bölümlerinde sesbilgisel farkındalığın bir ders olarak lisans programlarında yer alması önemlidir.

Sonuçlar olarak yukarıda ortaya konulan tüm bilgiler birlikte düşünüldüğünde, okul öncesi öğretmenlerin sesbilgisel farkındalık kavramına ilişkin bilgilerinin yetersiz olduğu görülmektedir. Sesbilgisel farkındalık kavramını, becerilerini ve bu becerilerin öğretmenler tarafında bilinmemesi uygulama ve değerlendirme kısmında da sorunlara yol açmaktadır. Erken dönemde kazanılması gerekli olan bu becerilerin okul öncesi öğretmenler tarafından bilinmemesi okul yaşamına hazırlanan çocukların akademik ve okuma başarısında sorunlara yol açmaktadır. Bu çalışma 17 okul öncesi öğretmen görüşü ile sınırlıdır. Bu yüzden genellemelerin yapılabilmesi için farklı öğretmen grupları ve sayıları ile farklı araştırmalar yapılmalıdır.

\section{Kaynaklar}

Adams, M.J. (1990). Beginning to read. Cambridge, MA: Harvard University Press.

Al-Bataineh, A. T. and Sims-King, S. (2013). The effectiveness of phonemic awareness instruction to early reading success in kindergarten. International Journal of Arts ve Sciences, 6(4), 59.

Altun, D. ve Tantekin-Erden, F. (2016). Okul öncesi öğretmen adaylarının erken okuryazarlık ile ilgili görüşleri ve staj uygulamaları. Kırşsehir Eğitim Fakültesi Dergisi, 17(1), 241-261.

Altun, D., Erden, F. T. and Snow, C. E. (2016). Filizlenen okuryazarlık: Okul öncesi dönem ses ve yazı farkındalığı becerilerini besleyen ev-içi kaynakların incelenmesi. Pegem Atıf İndeksi, 505-530.

Apel, K. and Lawrence, J. (2011). Contributions of morphological awareness skills to word-level reading and spelling in first-grade children with and without speech sound disorder. Journal of Speech, Language, and Hearing Research, 54(5), 1312.

Arıcı, D. ve Bartan, M. (2020). Çocuğu okul öncesi eğitime devam eden annelerin çocuklarına değer edindirme süreçlerinin incelenmesi. Ahi Evran Üniversitesi Sosyal Bilimler Enstitüsü Dergisi. 6(1). 279-294. https://doi.org/10.31592/aeusbed.640496 
Babayiğit, S., and Stainthorp, R. (2007). Preliterate phonological awareness and early literacy skills in Turkish. Journal of Research in Reading, 30(4), 394-413.

Baker, E. and McLeod, S. (2011). Evidence-based practice for children with speech sound disorders: Part 2 application to clinical practice. Language, Speech, and Hearing Services in Schools, 42, 102-139.

Barnett, W. S., Carolan, M. E., Squires, J. H., Clarke Brown, K. and Horowitz, M. (2015). The state of prekindergarten 2014: State preschool yearbook. New Brunswick: NJ: National Institute for Early Education Research Publications.

Baydık, B. (2003). Filizlenen okuryazarlık ve desteklenmesi. Ankara Üniversitesi Eğitim Bilimleri Fakültesi Özel Eğitim Dergisi, 4(2), 77-89.

Bradley, L. and Bryant, P. E. (1983). Categorizing sounds and learning to read-a causal connection. Nature, 301(5899), 419-421.

Bodle, K. (2019). Developing early literacy skills: Practical ldeas and activities. UK: Routledge.

Bos, C., Mather, N., Dickson, S., Podhajski, B. and Chard, D. (2001). Perceptions and knowledge of preservice and inservice educators about early reading instruction. Annals of Dyslexia, 51(1), $97-120$

Brady, S. A., Braze, D. and Fowler, C. A. (2011). Explaining individual differences in reading: Theory and evidence. New York: Psychology Press.

Bueno, M., Darling-Hammond, L. and Gonzales, D. (2010). A matter of degrees: Preparing teachers for the Pre-K classroom. Education Reform Series. US: Pew Center on the States.

Bueno, F. F., Fonseca, A. R., Braga, F. A. and Miranda, P. S. C. (2010). Qualidade do ar e internações por doenças respiratórias em crianças no município de Divinópolis, Estado de Minas Gerais. Acta Scientiarum. Health Sciences, 32(2), 185-189.

Cesur, C. and Demir, M. K. (2020). Okul öncesi eğitim alma süresinin çocukların sınıf kurallarına uyum ve okul motivasyonlarına etkisinin öğretmen görüşlerine göre incelenmesi. Ahi Evran Üniversitesi Sosyal Bilimler Enstitüsü Dergisi, 6(1), 103-122. https://doi.org/10.31592/aeusbed.643778.

Chetail, F. and Mathey, S. (2010). InfoSyll: A syllabary providing statistical information on phonological and orthographic syllables. Journal of psycholinguistic research, 39(6), 485-504.

Chu, M., Martínez-Griego, B. and Cronin, S. (2010). A Head Start/college partnership: Using a culturally and linguistically responsive approach to help working teachers earn degrees. $Y C$ Young Children, 65(4), 24.

Creswell, J. W. and Poth, C. N. (2016). Qualitative inquiry and research design: Choosing among five approaches. US: Sage publications.

Emir, C. (2015). Kaynaştırma ve genel ĕgitim öğretmenlerinin sesbilgisel farkındalı̆̆a ilişskin öğretim etkinliklerinin kullanımlarının incelenmesi. Yüksek Lisans Tezi. Anadolu Üniversitesi Eğitim Bilimleri Enstitüsü, Eskişehir. 
Emir, C., Girgin, M. C. and Karasu, H. P. (2015). Kaynaştırma ve Genel Eğitim Öğretmenlerinin Sesbilgisel Farkındalığa İlişki Öğretim Etkinliklerini Kullanımlarının İncelenmesi. Journal of Education and Special Education Technology, 1(1), 15-33.

Ergül, C., Karaman, G., Tufan, M., Sarıca, A. D. and Kudret, Z. B. (2014). Okul Öncesi Öğretmenlerinin Erken Okuryazarlık Kavramına İlişkin Bilgi Düzeyleri ve Sınıf Uygulamaları. Elementary Education Online, 13(4).

Evangelou, M. and Sylva, K. (2003). The effects of the peers early education partnership (PEEP) on children's developmental progress. Department of Educational Studies. 27-38.

Ferraz, I., Pocinho, M., Pereira, A. and Pimenta, A. (2015). Phonological awareness program: A longitudinal study from preschool to 4th grade. In SHS Web of Conferences (Vol. 16, p. 01002). EDP Sciences.

Fridriksson, J., Moser, D., Bonilha, L., Morrow-Odom, K. L., Shaw, H., Fridriksson, A. and Rorden, C. (2007). Neural correlates of phonological and semantic-based anomia treatment in aphasia. Neuropsychologia, 45(8), 1812-1822.

Gerde, H. K. (2019). Current practices for teaching letter and letter sound knowledge in preschool 1ncluding strategies for 1mproving instruction in these areas. NHSA Dialog, 22(2), 76-87.

Ciesielski, E. J. and Creaghead, N. A. (2020). The effectiveness of professional development on the phonological awareness outcomes of preschool children: A systematic review. Literacy Research and Instruction, 59(2), 1-27.

Gillon, G. T. and Young, A. A. (2002). The phonological-awareness skills of children who are blind. Journal of Visual Impairment ve Blindness, 96(1), 38-49.

Girgin, M. C. (2012). Öğretmen adaylarının sesbilgisel farkındalıklarına yönelik bir çalışma. Hacettepe Üniversitesi Eğitim Fakültesi Dergisi, 42(42), 186-193.

Gutiérrez-Palma, N., Naranjo, N. V., Justicia-Galiano, M. J. and Fernández, M. D. L. V. C. (2019). Beyond phonological awareness: Stress awareness and learning word spelling. Learning and Individual Differences, 74, 1041-1049.

Guimãraes, A. S. and Youngman, M. (1995). Portuguese preschool teachers' beliefs about early literacy development. Journal of Research in Reading, 18(1), 39-52.

Güldenoğlu, B., Kargın, T. and Ergül, C. (2016). Sesbilgisel farkındalık becerilerinin okuma ve okuduğunu anlama üzerindeki etkisi: Boylamsal bir çalışma. Elementary Education Online, 15(1).

Güldenoğlu, B., Kargin, T. and Miller, P. (2015). Okuma güçlüğü olan ve olmayan öğrencilerin cümle anlama becerilerinin incelenmesi. Türk Psikoloji Dergisi, 30(76), 82-96.

Güney, F. (2012). Okul öncesi öğretmenlerinin zihinsel yetersizliği bulunan öğrencilerin erken okuryazarlık becerilerinin desteklenmesine ilişkin görüşleri. Yüksek Lisans Tezi. Abant İzzet Baysal Üniversitesi Eğitim Bilimleri Enstitüsü, Bolu.

Hilbert, D. D. and Eis, S. D. (2014). Early intervention for emergent literacy development in a collaborative community pre-kindergarten. Early Childhood Education Journal, 42(2), 105113. 
Hogan, T. P., Catts, H. W. and Little, T. D. (2005). The relationship between phonological awareness and reading. Language, speech, and hearing services in schools, 36, 285-293

Hsin, Y. W. (2007). Effects of phonological awareness instruction on pre-reading skills of preschool children at-risk for reading disabilities. Doctoral Dissertation. The Ohio State University, USA.

Israel, S. E. (Eds.). (2007). Early reading first and beyond: A guide to building early literacy skills. US: Corwin Press.

Jaskolski, J. E. (2013). Effects of phonological awareness training on early childhood educators' knowledge, instructional practice and student outcomes. Cardinal Stritch University.

Kargın, T., Güldenoğlu, B. ve Ergül, C. (2017). Anasınıfı çocuklarının erken okuryazarlık beceri profili: Ankara örneklemi. Ankara Üniversitesi Ĕgitim Bilimleri Fakültesi Özel Ĕgitim Dergisi, 18(1), 61-87.

Kjeldsen, A. C., Kärnä, A., Niemi, P., Olofsson, A. and Witting, K. (2014). Gains from training in phonological awareness in kindergarten predict reading comprehension in grade 9. Scientific Studies of Reading, 18(6), 452-467.

Koutsoftas, A. D., Harmon, M. T. and Gray, S. (2009). The effect of tier 2 intervention for phonemic awareness in a response-to-intervention model in low-income preschool classrooms. Language, Speech, and Hearing Services in Schools, 40, 116-130.

Landry, S. H., Anthony, J. L., Swank, P. R. and Monseque-Bailey, P. (2009). Effectiveness of comprehensive professional development for teachers of at-risk preschoolers. Journal of educational psychology, 101(2), 448.

Lehr, F. and Osborn, J. (1994). Reading, language, and literacy: Instruction for the twenty-first century. Routledge Publications.

Lundberg, I., Frost, J. and Petersen, O. P. (1988). Effects of an extensive program for stimulating phonological awareness in preschool children. Reading research quarterly, 263-284.

Lundberg, I., Olofsson, Å. and Wall, S. (1980). Reading and spelling skills in the first school years predicted from phonemic awareness skills in kindergarten. Scandinavian Journal of psychology, 21(1), 159-173.

Maclean, M., Bryant, P. and Bradley, L. (1987). Rhymes, nursery rhymes, and reading in early childhood. Merrill-Palmer Quarterly, 33(3), 255-281.

Macrae, T., Tyler, A. A. and Lewis, K. E. (2014). Lexical and phonological variability in preschool children with speech sound disorder. American Journal of Speech-Language Pathology. 23(1), 27-35.

Marvelli, A. L. (2010). Highlights in the history of oral teacher preparation in America. Volta Review, 110(2).

Merriam, S. B. and Tisdell, E. J. (2009). Qualitative research: A guide to design and implementation. San Francisco. CA: John Wileyve Sons.

Metsala, J. L. (2011). Repetition of less common sound patterns: A unique relationship to young children's phonological awareness and word reading. International Journal of English Linguistics, 1(2), 3 . 
Nathan, L., Stackhouse, J., Goulandris, N. and Snowling, M. J. (2004). The development of early literacy skills among children with speech difficulties. Journal of Speech, Language, and Hearing Research.

Nielsen, D. C. and Luetke-Stahlman, B. (2002). Phonological awareness: One key to the reading proficiency of deaf children. American annals of the deaf, 147(3), 11-19.

Oliveira, C., Lousada, M. and Jesus, L. M. (2015). The clinical practice of speech and language therapists with children with phonologically based speech sound disorders. Child Language Teaching and Therapy, 31(2), 173-194.

Ong, F. (Ed.). (2008). California Preschool Learning Foundations: History-Social science. Science (Vol. 3). CA: California Department of Education.

Patton, M. Q. (2002). Qualitative research and evaluation methods. CA: Thousand Oakes.

Parpucu, N. ve Dinç, B. (2017). Seslerin renkli dünyası programının okul öncesi çocukların fonolojik farkındalık becerileri üzerindeki etkisi. Eğitim ve Bilim, 42(192), 233-261. http://dx.doi.org/10.15390/EB.2017.6864

Pullen, P. C. and Justice, L. M. (2003). Enhancing phonological awareness, print awareness, and oral language skills in preschool children. Intervention in school and clinic, 39(2), 87-98.

Rakhlin, N., Cardoso-Martins, C. and Grigorenko, E. L. (2014). Phonemic awareness is a more important predictor of orthographic processing than rapid serial naming: Evidence from Russian. Scientific Studies of Reading, 18(6), 395-414.

Robinson, S. J. (2013). Predicting third grade reading success from kindergarten phonological Awareness. Doctoral Dissertation. Walden University.

Robinson, S. (2010). The effects of embedded phonological awareness training on the reading and spelling skills of kindergarten students. ProQuest LLC. 789 East Eisenhower Parkway, PO Box 1346, Ann Arbor, MI 48106.

Seven, Y., Hull, K., Madsen, K., Ferron, J., Peters-Sanders, L., Soto, X., Kelley, E. S., and Goldstein, H. (2020). Classwide extensions of vocabulary intervention improve learning of academic vocabulary by preschoolers. Journal of Speech, Language, and Hearing Research, 63(1), 173189.

Scarborough, H. S. (2001). Connecting early language and literacy to later reading (dis)abilities: Evidence, theory, and practice. In S. B. Neuman ve D. Dickinson (Eds.), Handbook of early literacy research (pp. 97-110). New York: Guilford Press.

Schatschneider, C., Francis, D. J., Foorman, B. R., Fletcher, J. M. and Mehta, P. (1999). The dimensionality of phonological awareness: an application of item response theory. Journal of Educational Psychology, 91(3), 439.

Schatschneider, C., Fletcher, J. M., Francis, D. J., Carlson, C. D. and Foorman, B. R. (2004). Kindergarten prediction of reading skills: A longitudinal comparative analysis. Journal of Educational Psychology, 96(2), 265.

Schuele, C. M., Skibbe, L. E. and Rao, P. K. (2007). Assessing phonological awareness. Assessment in Emergent Literacy, 275-327. 
Scott, J. A., Goldberg, H., Connor, C. M. and Lederberg, A. R. (2019). Schooling effects on early literacy skills of young deaf and hard of hearing children. American Annals of The Deaf, 163(5), 596-618.

Sulzby, E. and Teale, W. (1991). Emergent literacy. Handbook of reading research, 2, 727-757.

Şimşek, H. ve Yıldırım, A. (2011). Sosyal bilimlerde nitel araştırma yöntemleri. Ankara: Seçkin.

Thomas, L. J., Gerde, H. K., Piasta, S. B., Logan, J. A., Bailet, L. L. and Zettler-Greeley, C. M. (2020). The early writing skills of children identified as at-risk for literacy difficulties. Early Childhood Research Quarterly, 51, 392-402.

Tomblin, J. B., Oleson, J., Ambrose, S. E., Walker, E. A. and Moeller, M. P. (2020). Early literacy predictors and second-grade outcomes in children who are hard of hearing. Child Development, 91(1), 179-197.

Torgesen, J. K., Wagner, R. J. and Rashotte, C. A. (1994). Longitudinal studies of phonological processing and reading. Journal of Learning Disabilities, 27, 276-286.

Turan, F. ve Akoğlu, G. (2014). Okul öncesi dönemde ev okuryazarlık ortamı ve fonolojik farkındalık becerileri. Hacettepe Üniversitesi Ĕgitim Fakültesi Dergisi, 29(3), 153-166.

Webb, M. Y. L., Schwanenflugel, P. J. and Kim, S. H. (2004). A construct validation study of phonological awareness for children entering prekindergarten. Journal of Psychoeducational Assessment, 22(4), 304-319.

Whitebook, M. and Ryan, S. (2011). Degrees in context. NJ: National Institute of Early Education Research.

Whitehurst, G. J. and Lonigan, C. J. (1998). Child development and emergent literacy. Child Development, 69(3), 848-872.

Wilcox, M. J., Gray, S. and Reiser, M. (2020). Preschoolers with developmental speech and/or language impairment: Efficacy of the teaching early literacy and language (TELL) curriculum. Early Childhood Research Quarterly, 51, 124-143.

Withrow, K. (2014). Preschool Teachers' Understanding of Phonological Awareness. Doctoral Dissertation. California State University, USA.

Wright, J. and Jacobs, B. (2003). Teaching phonological awareness and metacognitive strategies to children with reading difficulties: A comparison of two instructional methods. Educational Psychology, 23(1), 17-47.

Yeh, S. S. and Connell, D. B. (2008). Effects of rhyming, vocabulary and phonemic awareness instruction on phoneme awareness. Journal of Research in Reading, 31(2), 243-256.

Yıldırım, B. (2015). İçerik çözümlemesi yönteminin tarihsel gelişimi uygulama alanları ve aşamaları. B. Yıldırım (Der.). Iletişim araştırmalarında yöntemler: Uygulama ve örneklerle içinde (s. 105-155). Konya: Literatürk Akademia.

Yopp, H. K. and Yopp, R. H. (2009, January). Phonological awareness is child's play! Beyond the Journal: Young Children on the Web. Retrieved from http://www.naeyc.org/files/yc/file /200901/BTJPhonologicalAwareness.pdf

Yopp, H.K. and Yopp, R.H. (2000). Supporting phonemic awareness development in the classroom. The Reading Teacher, 54, 130-143. 


\section{Extended Abstract}

\section{Introduction}

When the relationship between reading performance and academic achievement is analyzed, it is stated that students with insufficient reading skills are not expected to be interested in different course subjects, understand what they read in their textbooks and perform successfully in academic fields, as well as the delays in reading skills that will affect students' academic life negatively. (Güzel, 1998). The role of phonological awareness knowledge and skills in learning to read and write is a very important issue. (Moats, 2010). It is possible to define a successful reading activity as a process where readers analyze the words in written texts by using appropriate orthographic, phonological, morphological knowledge and skills, then interpret the analyzed words by associating them with their existing vocabulary, previous knowledge and experience, and then reach the desired message by analyzing the sentences consisting of the words they interpreted in the context of their syntactic features (Güldenoğlu, Kargın and Miller, 2016). Accordingly, readers who have sufficient phonological knowledge and skills will be more successful in word analysis and reading comprehension skills than readers with poor phonological knowledge and skills. (Güldenoğlu et al., 2016). Concerns about whether preschool teachers have knowledge about the meaning of phonological awareness and whether they have expertise to teach phonological awareness skills are also included in the literature (Bos, Mather, Dickson, Podhajski, and Chard, 2001). The absence of research on the knowledge and skills of teachers about the concept of phonological awareness further raises concerns about the expectations and consistencies required for student success in various schools and learning environments in the field of literacy acquisition (Whitebook and Ryan, 2011). In phonological awareness interventions, trainers and teachers ask questions about how the activities should be done, how much time should be allocated to the activities, which type of training would be appropriate, how the training program would be developed and how the contents of the intervention programs would be prepared (Yopp and Yopp, 2000). According to the findings obtained from the studies, teachers are of great importance in giving phonological awareness skills to children (Truxler and O 'Keede, 2007). In this direction, it was tried to reveal the knowledge levels and classroom practices of preschool teachers on the concept of phonological awareness.

\section{Method}

This study is structured within the scope of qualitative research methods. In this study, interview technique, one of the qualitative research methods, was used. Themes were created from the answers given by the preschool teachers to the structured interview form and the relationships among the responses were analyzed. Convenience sampling method was used to form the study group. The study was conducted with 18 preschool teachers working in different schools with different socioeconomic levels in Kurşehir city center. Regarding the seniority of the preschool teachers who participated in the study, 4 teachers' seniority was between $0-5$ years, 5 teachers' between $5-10$ years, 3 teachers' between 10-15 years, 6 teachers' between 15-20 years. All of the teachers participating in the study have bachelor's degree. 17 of these teachers were graduated from pre-school undergraduate education and 1 of them was graduated from 4-year child development department. Within the scope of the interview form, questions addressing the following issues were asked: how teachers define the concept of phonological awareness, their knowledge about the development and levels of phonological awareness skills, their thoughts about the importance of the concept of phonological awareness, the activities they perform in the classroom in order to increase children's phonological awareness knowledge and skill levels, the issues they take into consideration in the preparation of activities, the way of assessing children's phonological awareness skills and the difficulties they experience in giving these skills to children. Two experts in their field independently analyzed written records and identified the themes related to the questions. Identified themes were compared, and common themes were created. Credibility (internal validity) and transferability (external validity) and reliability criteria were used to ensure the validity and reliability of the study 


\section{Result, Discussion and Conlusion}

The concept of phonological awareness was defined by preschool teachers as "Speech Sounds, Grammar Rules, Using Language Correctly". Regarding these definitions made by preschool teachers, it is clear that teachers do not know the concept of phonological awareness. Considering the results of another question asked to teachers in the study about the development and the levels of phonological awareness skills, teachers' responses were as "these skills show a natural, auditory development with age". The analysis to the question about the type of activities that teachers created for phonological awareness skills and the issues that they paid attention in the development of these activities showed that they stated to perform the activities of adding sound to words, finding words with the same first sound, and also storytelling, riddle games, finger games and teaching the vowels of the alphabet. When teachers were asked about the methods used to assess phonological awareness skills in preschool children, it was seen that most of them didn't make any assessment whereas some others evaluated according to whether the children completed the activities. Regarding the results related to the problems faced by teachers in giving phonological awareness skills, it was concluded that phonological awareness concepts create difficulties for children due to the individual differences among them.

As a result, when all the facts presented above are considered together, it is seen that preschool teachers have insufficient knowledge about the concept of phonological awareness. The fact that the concept of phonological awareness and related skills are not known by the teachers also causes problems in the application and assessment part. Not to be known of these skills required to be acquired in the early period by the preschool teacher causes problems in academic and reading success of the children preparing for school life. 